\title{
New Organometallic Technetium Complexes in High and Low Oxidation States
}

\author{
By Roger Alberto ${ }^{1}$, Wolfgang A. Herrmann ${ }^{2 a}$, Jeff C. Bryan ${ }^{3}$, P. August Schubiger ${ }^{1}$, Franz Baumgärtner ${ }^{2 b}$ \\ and Dimitrios Mihalios ${ }^{2 \mathrm{a}}$ \\ 1 Paul Scherrer Institute, Division of Radiopharmacy CH-5323 Villigen, Switzerland \\ 2 Technische Universität München, Institut für Anorganische Chemie ${ }^{a}$ /Radiochemie ${ }^{b}$, D-85748-Garching, Germany \\ 3 Los Alamos National Laboratory, INC-4, Los Alamos NM 87545, USA
}

(Received April 16, 1993)

$\mathrm{CH}_{3} \mathrm{TcO}_{3} /$ Oxidation catalysis / Carbonylation / Tc(I) and $\operatorname{Re}(\mathrm{I})$-cluster / Tridentate ligands / Isocarbonyl
As for the oxidation state + VII relatively little chemistry has been done for the + I state [8]. Since Tcchemistry was often provoked by a possible application in radiodiagnostics $\mathrm{Tc}(\mathrm{I})$ seemed not to be very interesting, owing to the fact that this state typically belongs to the field of organometallic chemistry. This opinion was dramatically contradicted by the easy synthesis of Davisons $\left[\mathrm{Tc}(\mathrm{CNR})_{6}\right]^{+}[9]$ or more recently by Westers $\left[\mathrm{Tc}\left(\mathrm{C}_{6} \mathrm{H}_{6}\right)_{2}\right]^{+}[10]$. A second reason is the difficulty in synthesizing homoleptic Tc-carbonyls, the most useful and common starting material for the development of low valency Tc-complexes. Literature routes end up with often poor yield $[11,12]$ and safety reasons are a hinderance to high pressure reactions with radioactive material. By lowering $\mathrm{CO}$ pressure we were able to synthesize selectively and in high yield a reactive $\mathrm{Tc}(\mathrm{I})$-cluster. It is obvious from reaction conditions that this cluster system is readily formed as an intermediate during the reduction step. Its interesting structure and subsequent reactions are presented. Further investigations with rhenium at different CO-pressures resulted in similar clusters with the difference that the reactions occured very much faster in the technetium case.

\section{Synthesis, characterization and catalytic properties of $\mathrm{CH}_{3} \mathrm{TcO}_{3}$}

Original synthesis of $\mathrm{CH}_{3} \mathrm{ReO}_{3}$ was straight forward and resulted in a $50 \%$ yield of the compound [13]. Reaction conditions were relatively severe, refluxing the solution in THF for 5-6h. Under the same conditions we were not able to isolate the desired Tcproduct as can be seen from Figure 2 .

Instead, a $50 \%$ yield of the trimethylstannylester 4 was isolated as well as around $40 \%$ (relative to $\mathrm{Tc})$ of the dimeric $\mathrm{Tc}(\mathrm{VI})$ compound 7 . This orange product is easily sublimable, soluble in all kinds of organic solvents and stable in air. Its structure has been determined (Figure 3) [14]. It is well possible that compound $\mathbf{2}$ is formed as an intermediate but that it is readily reduced further to the $\mathrm{Tc}(\mathrm{VI})$ compound 7 . With strong reducing agents such as $\mathrm{Zn}\left(\mathrm{CH}_{3}\right)_{2}$ the analog Re complex can be synthesized. The fact that the stannyl ester is formed as well supports this as- 
<smiles></smiles>

$\underline{3}$

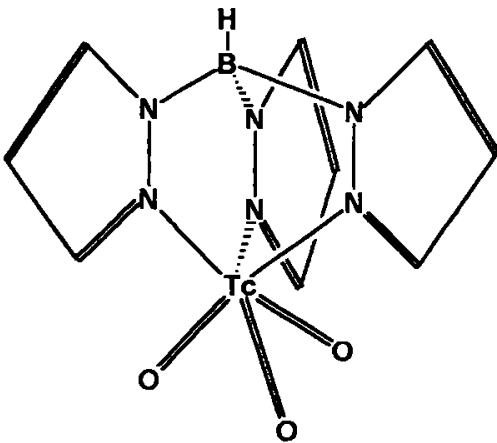

$\underline{5}$

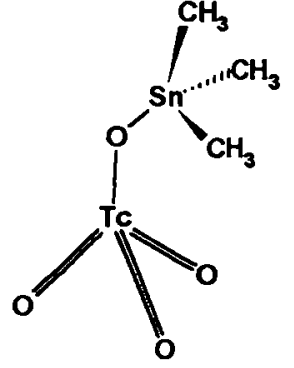

$\underline{4}$

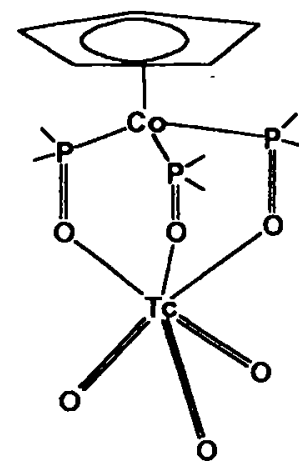

Fig. 1. Some $\mathrm{Tc}(\mathrm{VII})$ complexes containing the " $\mathrm{TcO}_{3}$ " core

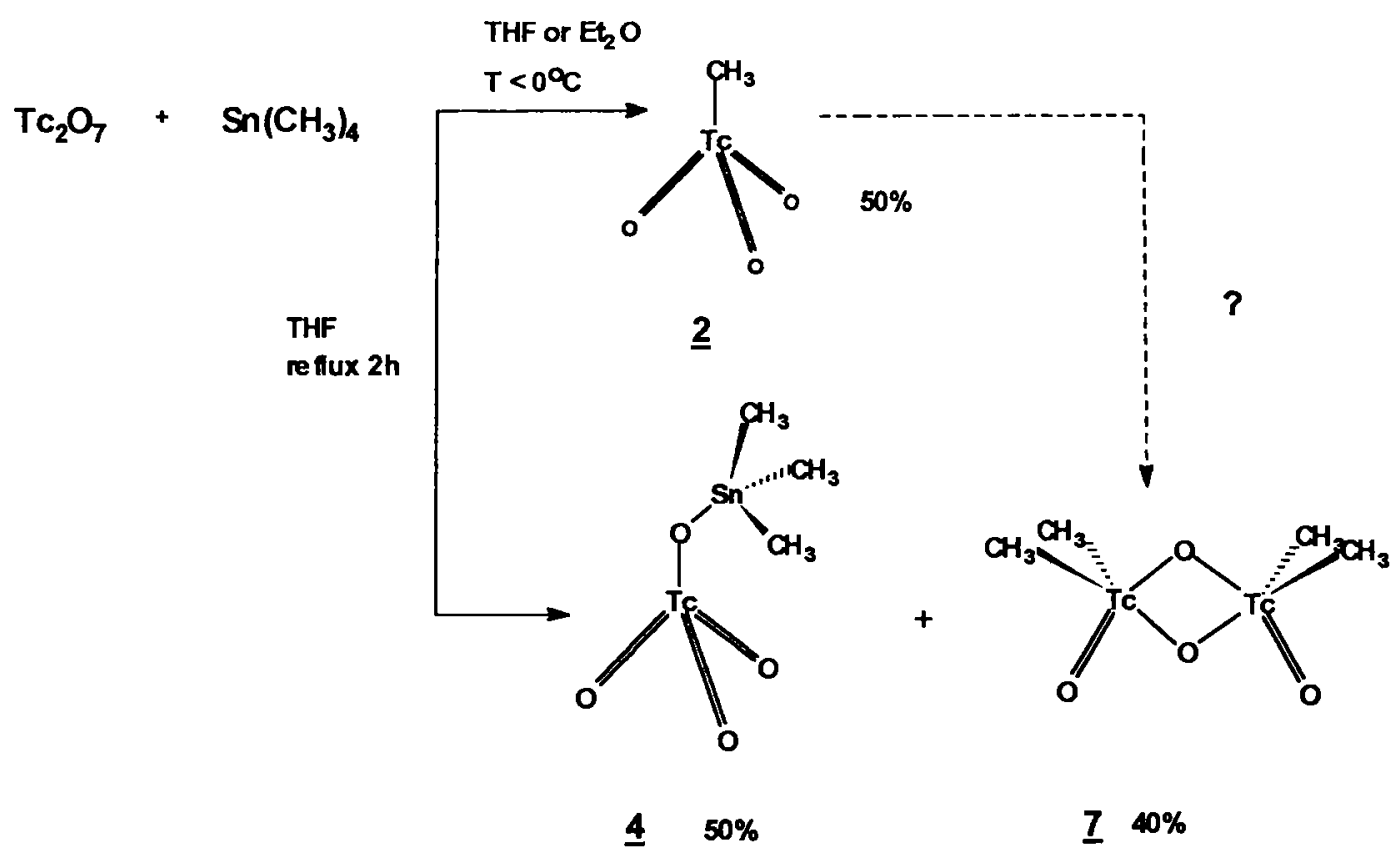

Fig. 2. Reaction conditions for the synthesis of compound 2, 4 and 7. 


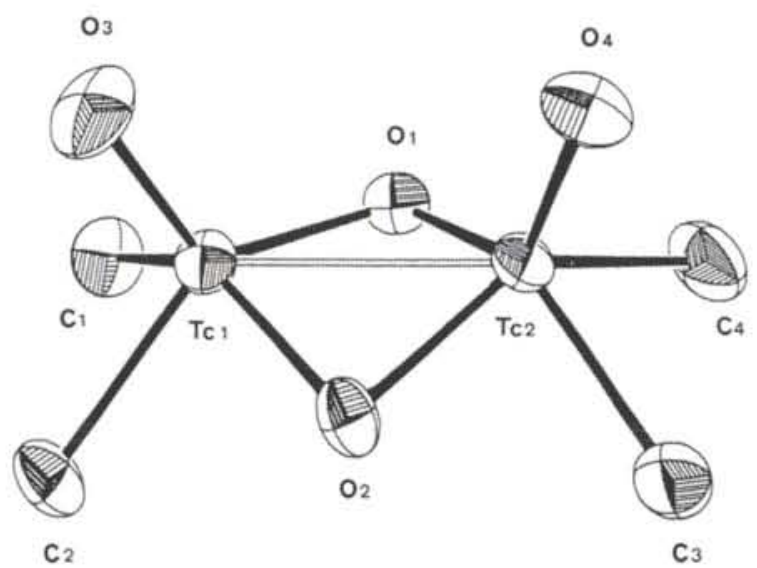

Fig. 3. ORTEP drawing of the complex $\left[\left(\mathrm{CH}_{3}\right)_{4} \mathrm{Tc}_{2} \mathrm{O}_{4}\right]$. Thermal ellipsoids are at the $50 \%$ probability level.

sumption. The course of the reaction indicates also that the difference in redox potential influences the chemistry significantly. The structure of compound 7 is isomorphous to that of rhenium. The $\mathrm{Tc}-\mathrm{Tc}$ distance of $256.17(3)$ pm could give rise to a $\mathrm{Tc}-\mathrm{Tc}$ single bond. Extreme line broadening in ${ }^{1} \mathrm{H}$ and ${ }^{99} \mathrm{Tc}-\mathrm{NMR}$ suggests the compound to be paramagnetic, thus contradicting the assumption of a $\mathrm{Tc}-\mathrm{Tc}$ single bond.

The synthesis of $\mathrm{CH}_{3} \mathrm{TcO}_{3}$ was finally done at low temperature, at best below $-20^{\circ} \mathrm{C}$. Running the reaction at $0^{\circ} \mathrm{C}$ the solution slowly turned orange but nevertheless $\mathrm{CH}_{3} \mathrm{TcO}_{3}$ could be isolated. This coloring of the solution obviously resulted from formation of small amounts of compound 7 .

$\mathrm{CH}_{3} \mathrm{TcO}_{3}$ is an extremely volatile compound that can be sublimed at room temperature and atmospheric pressure. It forms long white needles if sublimed at $-78^{\circ} \mathrm{C}$. It is stable at room temperature and decomposes on hot parts only forming probably $\mathrm{TcO}_{3}$ and $\mathrm{C}_{2} \mathrm{H}_{6}$. It is soluble in all solvents including water. Stock solutions were usually prepared in hexane at low temperature. It has been characterized by ${ }^{1} \mathrm{H}-$ NMR, ${ }^{99} \mathrm{Tc}-\mathrm{NMR}, \mathrm{MS}$ and IR-spectroscopy. An important difference to its rhenium analog is the fact that no phenantroline or bipyridile adduct could be precipitated. This can be done with $\mathrm{CH}_{3} \mathrm{ReO}_{3}$ to stabilize the coordinatively unsaturated $\mathrm{CH}_{3} \mathrm{ReO}_{3}$ unit [15]. On adding one of these bases intense red solutions were obtained, which decomposed on concentrating. The assumption that this behaviour could be due to high $\mathrm{C}-\mathrm{H}$ acidity i.e. that we have a kind of acid/base equilibrium, is interesting but could not be proven.

\section{Catalytic reactions}

It is well established that $\mathrm{CH}_{3} \mathrm{ReO}_{3}$ acts as a powerful epoxidation catalyst of alkenes. Subsequent hydrolyzation ends up with either trans-diolates (alkaline) or mixture of cis/trans-diolates (acidic). When a solution of $\mathrm{CH}_{3} \mathrm{TcO}_{3}$ was mixed with stoichiometric amounts of an alkene an intense yellow color formed immediately. On addition of water a black precipitate formed readily and $\mathrm{TcO}_{4}^{-}$could be detected chromatographically. $\mathrm{Tc}(\mathrm{V})$ compounds are known to undergo easy disproportion to Tc(IV) and Tc(VII). The assumption that compound $\mathbf{8}$ (Figure 4 ) is formed can therefore be proven indirectly. GC/MS investigations of the remaining solution allowed the detection of diols. We especially used cyclohexene as a model to investigate stereochemistry. Derivatization of the diols with trimethylsilylchloride allowed us to differ between the trans and the cis isomere on a special GC column. We found that the cis-isomer was formed specifically. The mechanism of reduction and formation of the intermediate $\mathbf{8}$ which could not be isolated seemed to be similar to that with $\mathrm{OsO}_{4}$ described by Sharpless et al. [16]. If the reaction is carried out in the presence of water free $\mathrm{H}_{2} \mathrm{O}_{2}$ in tert.- $\mathrm{BuOH}$ this process occurs also catalytically (Figure 4). In the case of cyclohexene the yield of cis-1,2-cyclohexanediol was $83 \%$ for a ratio catalyst/alkene $=1: 100$. Presence of small amounts of water interrupt the catalytic cycle by hydrolyzing the reduced form of the catalyst. It could be observed that black precipitates formed as the reaction went on.

Davison et al. used $\mathrm{TcClO}_{3}$ phen for a similar purpose [17]. On reacting this compound with alkene (e.g. ethene) a stable $\mathrm{Tc}(\mathrm{V})$ complex was formed by reduction. It was not tried to run the cycle catalytically but since this compound is coordinatively saturated it is unlikely that the process runs under mild conditions. For the analog $\mathrm{Re}(\mathrm{VII})$ complex $\left[\mathrm{ReClO}_{3}\right.$ phen $]$ a completely different behaviour was found in that this compound did not add alkenes but the otherwise prepared [ $\mathrm{ReOCl}($ phen $\left.)\left(\mathrm{OCH}_{2} \mathrm{CH}_{2} \mathrm{O}\right)\right]$ released alkenes on heating to form $\left[\mathrm{ReClO}_{3}\right.$ phen].

The differences between $\operatorname{Re}(\mathrm{VII})$ and $\mathrm{Tc}(\mathrm{VII})$ reveal that chemistry in this oxidation state is not only gradual but fundamentally different. Figure 5 gives an excerpt of the periodical table. Manganese and ruthenium are related to each other in that there highest oxides cleave carbon carbon double bonds and the alkenes end up as carbonyls. Technetium and osmium on the other hand react smoother and oxidize stereospecifically to cis-diolates (derivatives). Rhenium at least is able to epoxidize alkenes in the presence of peroxides.

\section{New $\operatorname{Tc}(\mathrm{I})$ and $\operatorname{Re}(\mathrm{I})$ compounds}

Another aspect of our recent work on organometallic technetium complexes was to find an easy access to reactive $\mathrm{Tc}(\mathrm{I})$ compounds. The usual approach is the complete carbonylation of $\mathrm{Tc}_{2} \mathrm{O}_{7}$ or $\mathrm{TcO}_{2}$ under high pressure and temperature to form the long known $\mathrm{Tc}_{2}(\mathrm{CO})_{10}$ as starting material $[18,19]$. Yields are moderate and the procedure, especially in the case of 

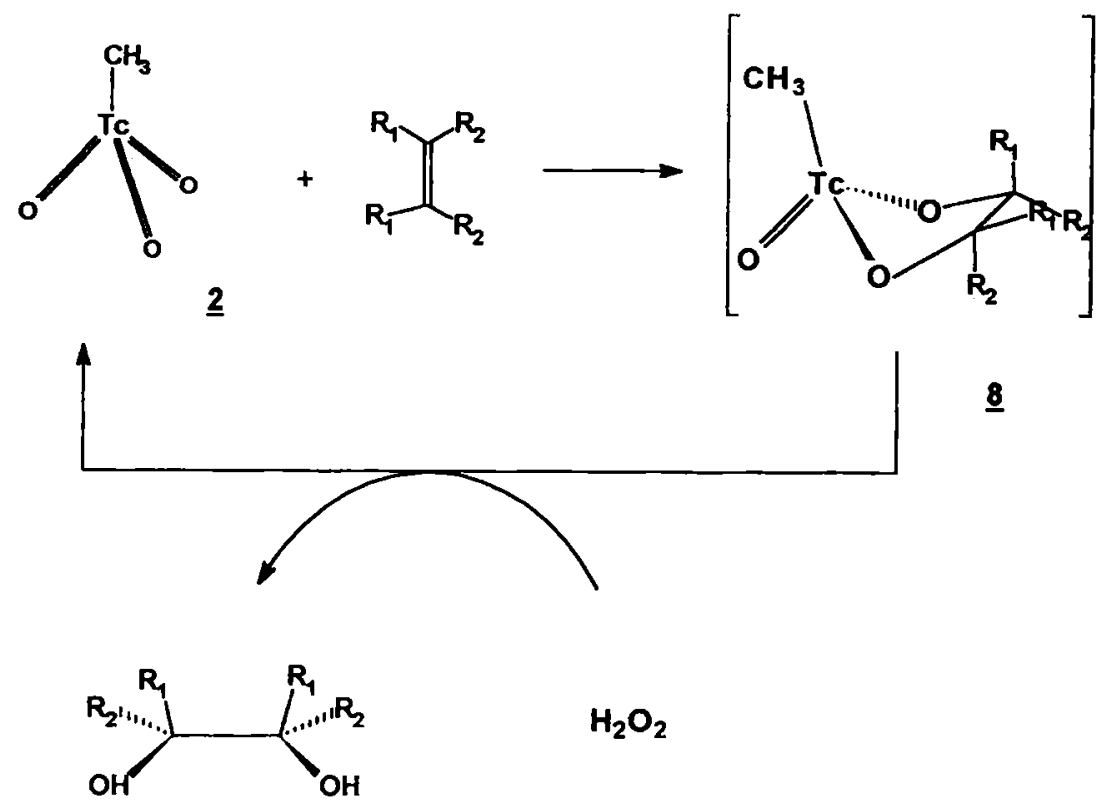

Fig. 4. Catalytic cycle for the oxidation of alkenes using $\mathrm{CH}_{3} \mathrm{TcO}_{3}$ as catalyst.

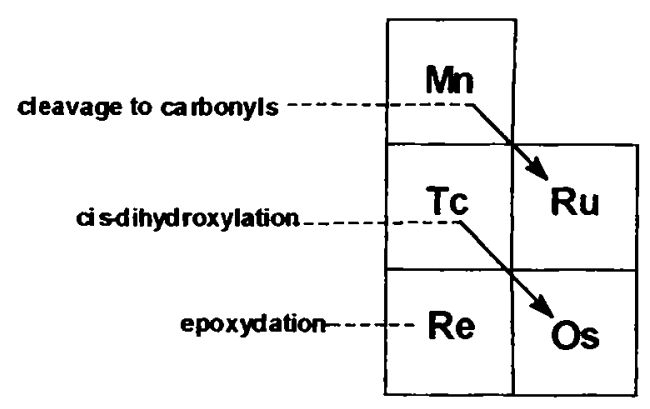

Fig. 5. Excerpt of the periodical system showing relations of oxidativ behaviour against alkenes.

sensitive $\mathrm{Tc}_{2} \mathrm{O}_{7}$, is complicated. Investigation of the formation of possible intermediates formed during this seven electron reduction step has not been done for the group $7 \mathrm{a}$ and scarcely for other elements. Preferable, in the presence of a potential coordinating solvents it is to be expected that stable intermediates are formed. We intended to prepare selectively such intermediates by control of pressure, temperature and reaction time. We used $\mathrm{NaTcO}_{4}$ as starting material and $\mathrm{CH}_{3} \mathrm{OH}$ as solvent for the above mentioned reasons. Heinekey et al. described a procedure to prepare $\operatorname{Re}_{2}(C O)_{10}$ in high yield [20]. Figure 6 gives an overview on our reaction conditions.

Heinekeys protocol could also be reproduced with technetium resulting in high yield access to $\mathrm{Tc}_{2}(\mathrm{CO})_{10}$. Varying thermodynamic conditions such as pressure, temperature and time we isolated in good yield the cluster-like intermediate $\mathrm{Na}\left[\mathrm{Tc}_{3}(\mathrm{CO})_{9}\left(\mu_{3}-\mathrm{OCH}_{3}\right)\left(\mu_{2^{-}}\right.\right.$ $\left.\left.\mathrm{OCH}_{3}\right)_{3}\right]$ 9. It is formed in over $75 \%$ yield after only $2 \mathrm{~h}$ of reaction time at conditions which are moderate compared to a total carbonylation. 9 can subsequently be further reduced to $\mathrm{Tc}_{2}(\mathrm{CO})_{10}$ by applying the original conditions. It seems that the reduction to $\mathrm{Tc}(\mathrm{I})$ goes very quickly while the further one electron reduction step is very slow. It is to be expected that $\mathrm{Na}\left[\mathrm{Tc}_{3}(\mathrm{CO})_{9}\left(\mu_{3}-\mathrm{OCH}_{3}\right)\left(\mu_{2}-\mathrm{OCH}_{3}\right)_{3}\right]$ is not the only intermediate formed but it may be in the technetium case the only one that is present in high steady state concentrations [21]. This described cluster 9 is the first trinuclear $\mathrm{Tc}(\mathrm{I})-\mathrm{CO}$ cluster. Its structure could be elucidated and revealed some special features. A "Schakal" presentation is given in Figure 7.

Even though there are only three Tc-atoms the basic frame is that of a cube. The sodium atom included in the formula does not just act as a counterion but is strongly included in the cluster system. Neither in acetonitrile, ethanol nor in a water/acetonitrile mixture could any conductivity be measured. Therefore the moiety $\left[\mathrm{Tc}_{3}(\mathrm{CO})_{9}\left(\mu_{3}-\mathrm{OCH}_{3}\right)\left(\mu_{2}-\mathrm{OCH}_{3}\right)_{3}\right]^{-}$can be described as an anionic crown ether with high stability toward sodium. Another interesting speciality is the detection of isocarbonyl bonding between a sodium atom from one cluster and a $\mathrm{CO}$ from a neighbouring unit, forming thus indefinitely long cluster chains linked by Tc-C-O-Na. The sodium is further coordinated by two $\mathrm{CH}_{3} \mathrm{CN}$ molecules and uses one $\mathrm{CO}$ to saturate its coordination sphere. Only a few isocarbonyl complexes are known [22]. The bond length of $251.0(5) \mathrm{pm}$ lies at the upper range of determined C-O--Na distances.

The described $\mathrm{Na}\left[\mathrm{Tc}_{3}(\mathrm{CO})_{9}\left(\mu_{3}-\mathrm{OCH}_{3}\right)\left(\mu_{2^{-}}\right.\right.$ $\left.\mathrm{OCH}_{3}\right)_{3}$ is not only an interesting structure but a very versatile educt for subsequent $\mathrm{Tc}(\mathrm{I})$ chemistry. The coordinated methanolato groups are strongly labilized by trans effect of carbonyls and are thus easily substituted. Figure 8 gives some examples of such reactions which can all be performed in good yields. Again ${ }^{99} \mathrm{Tc}$ NMR of the three complexes has been done. It shows that 11 and 12 fall inside the range proposed for $\mathrm{Tc}(\mathrm{I})$ 


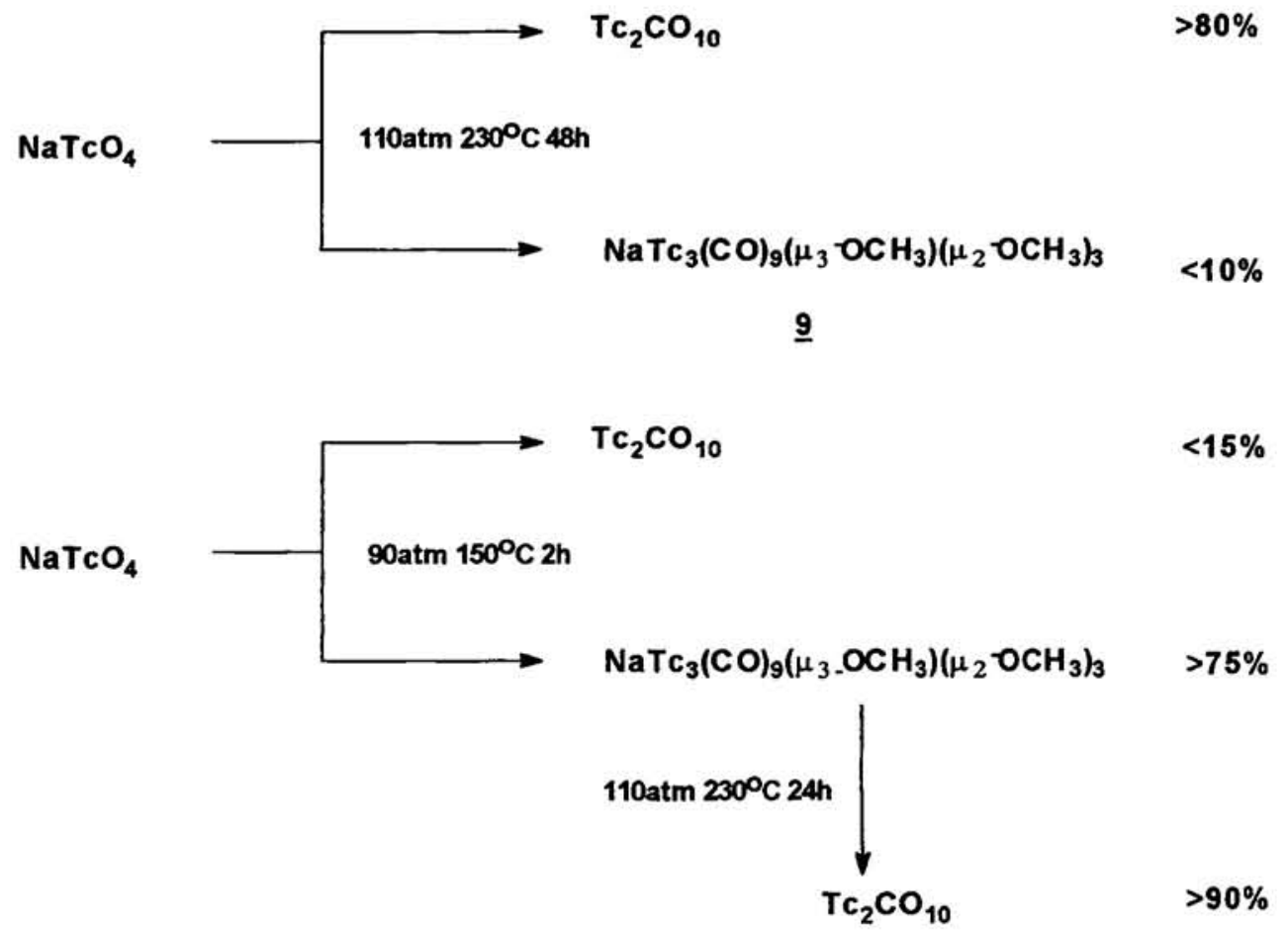

Fig. 6. Carbonylation of $\mathrm{NaTcO}_{4}$ : product distribution under different conditions.

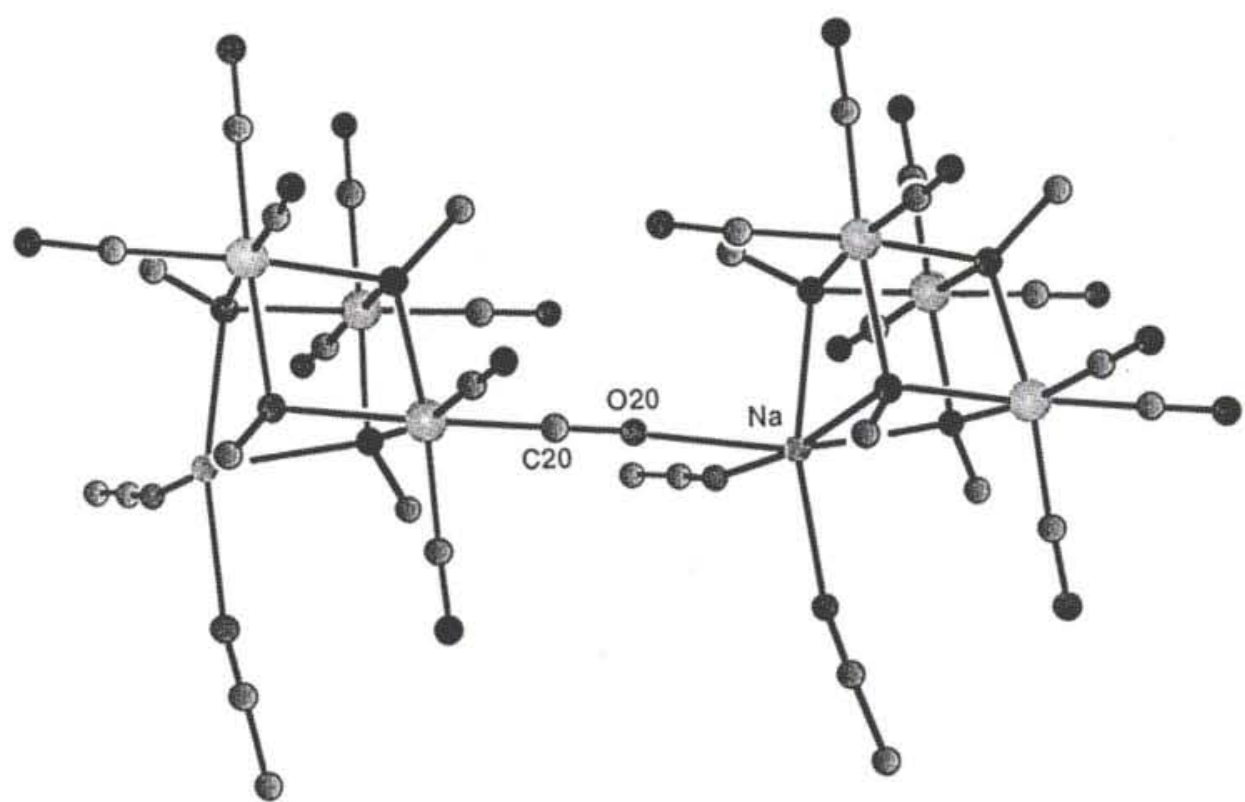

Fig. 7. "Schakal" presentation of two $\left[\mathrm{NaTc}_{3}(\mathrm{CO})_{9}\left(\mathrm{OCH}_{3}\right)_{4}\right]$ units linked by the isocarbonyl bond "O20 - Na".

complexes while $\mathbf{1 0}$ resonates rather far outside this range [23].

\section{Investigation on $\operatorname{Re}(\mathbf{I})$-clusters}

To compare rhenium and technetium similar carbonylations have been done with perrhenate. Figure 9 gives the results. Again, at high pressure and temperature $\operatorname{Re}_{2}(\mathrm{CO})_{10}$ was obtained in high yield. At decreased pressure but same temperature and time, a dinuclear $\operatorname{Re}(\mathrm{I})$ complex $\quad\left[(\mathrm{CO})_{3} \operatorname{Re}\left(\mu_{2}-\mathrm{OCH}_{3}\right)_{3}\right.$ $\left.\operatorname{Re}(\mathrm{CO})_{3}\right]^{-} 13$ was found in almost quantitative yield [24]. Another decrease in pressure by $50 \%$ leaving time and temperature almost the same gave in $60 \%$ yield the same trinuclear $\operatorname{Re}(\mathrm{I})$-cluster $\left[\mathrm{Re}_{3}(\mathrm{CO})_{9}\left(\mu_{3}\right.\right.$ $\left.\left.\mathrm{OCH}_{3}\right)\left(\mu_{2}-\mathrm{OCH}_{3}\right)_{3}\right]^{-} 14$ as in the technetium cases. A further decrease in pressure down to $20 \mathrm{~atm}$ yielded low amounts of a tetranuclear cluster. Elemental analysis as well as mass spectroscopy indicates a $\mu_{3}$ oxo included into the structure. Investigations on this matter are to be pursued. 


\section{$\mathrm{NaTc}_{3}(\mathrm{CO})_{9}\left(\mu_{3}-\mathrm{OCH}_{3}\right)\left(\mu_{2}-\mathrm{OCH}_{3}\right)_{3}$}

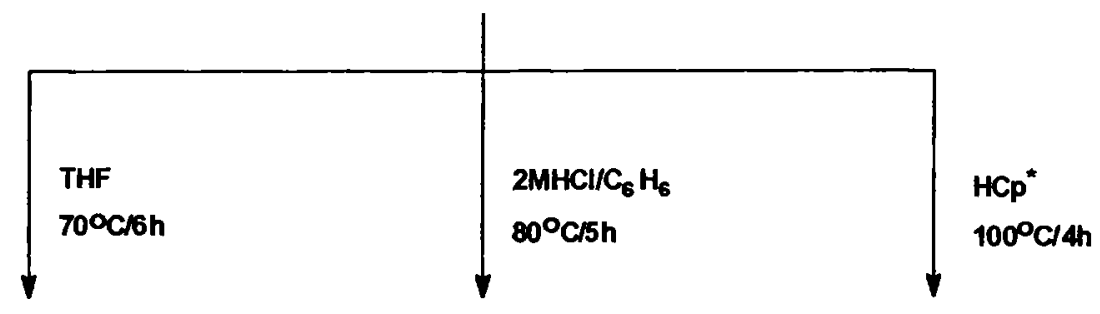

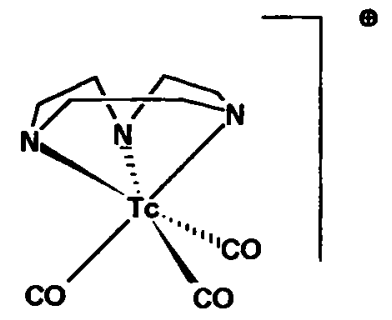

10

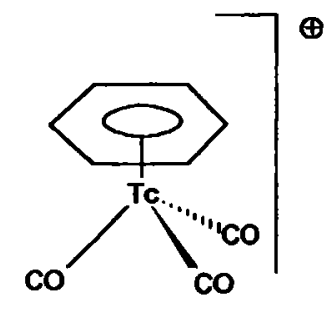

11

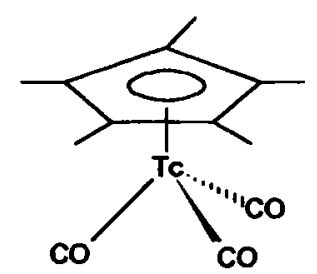

12

$\delta$ 99Tc-NMR: -1012ppm

-1983ppm

-1874ppm

Fig. 8. Substitution reactions on $\left[\mathrm{NaTc}_{3}(\mathrm{CO})_{9}\left(\mathrm{OCH}_{3}\right)_{4}\right]$ using tridentate facial coordinating ligands.

It seems that during the reduction process of perrhenate a lot of (extractable) intermediates are formed. They can be selectively obtained through pressure and temperature control. The conditions to yield, for example, the trinuclear unit $\left[\operatorname{Re}_{3}(\mathrm{CO})_{9}\left(\mu_{3^{-}}\right.\right.$ $\left.\left.\mathrm{OCH}_{3}\right)\left(\mu_{2}-\mathrm{OCH}_{3}\right)_{3}\right]^{-}$are much stronger than in the technetium case. This mirrors again the often observed effect that technetium reacts much more readily than rhenium and that the former is easier to reduce than the latter. To achieve the same yield of as in the case of 9 , reaction times have to be twenty times as long as for 9 . To prove that solubilities are not responsible for the observed delayed kinetic the same reactions were done using $\mathrm{NaReO}_{4}$. Under similar conditions similar yields and species were obtained.

The structure of the not yet described dimeric compound 13 was resolved. It consists of two facial " $\operatorname{Re}(\mathrm{CO})_{3}$ " moieties linked by three bridging methanolato groups. The $\mathrm{Re}-\mathrm{Re}$ distance is $311.3 \mathrm{pm}$ and a single bond can therefore be excluded.

\section{Oxidation of $\mathrm{Cp}^{*} \mathbf{T c}(\mathrm{CO})_{3}$}

The oxidation of $\mathrm{Cp}^{*} \mathrm{Re}(\mathrm{CO})_{3}$ was originally done with a two layer system consisting of benzene and $\mathrm{H}_{2} \mathrm{O}_{2} / \mathrm{H}_{2} \mathrm{SO}_{4}$ in moderate yield. We developed a much faster and higher yield synthesis of $\mathrm{Cp}^{*} \mathrm{ReO}_{3}$ by using $\mathrm{Mn}_{2} \mathrm{O}_{7}$ in acetone or $\mathrm{CCl}_{4}$ as oxidizing agent [25]. This powerful oxidant is able to transform $\mathrm{Cp} * \operatorname{Re}(\mathrm{CO})_{3}$ in minutes to the desired product. In the technetium case we hoped to apply the same method. Oxidation with $\mathrm{H}_{2} \mathrm{O}_{2}$ to $\mathrm{Cp}^{*} \mathrm{TcO}_{3}$ failed and we could not even isolate the polymer $\left[\mathrm{Cp}^{*} \mathrm{Tc}_{2} \mathrm{O}_{3}\right]_{\mathrm{n}}$ described by Kanellakopu- los and coworkers [26]. The attempt to oxidize with $\mathrm{Mn}_{2} \mathrm{O}_{7}$ failed as well and the observation was made that some reactive intermediate or the educt technetium compound catalytically decomposed $\mathrm{Mn}_{2} \mathrm{O}_{7}$. Adding one drop of a Cp* $\mathrm{Tc}(\mathrm{CO})_{3}$ solution to $\mathrm{Mn}_{2} \mathrm{O}_{7}$ in $\mathrm{CCl}_{4}$ at $-78^{\circ} \mathrm{C}$ induced readily the evolution of a gas $\left(\mathrm{O}_{2}\right)$ and the formation of bulky $\mathrm{MnO}_{2}$ was observed. Using other oxidants such as dimethyldioxirane as described by Wolowiec et al. [27] we found no $\mathrm{Cp}^{*} \mathrm{TcO}_{3}$ but recovered the educt quantitatively.

\section{Synthesis and reactions of complexes containing the “mer-Tc(I)(CO) ${ }_{2} \mathrm{P}\left(\mathrm{C}_{6} \mathrm{H}_{5}\right)_{3}$ " moiety}

Beside the not readily available " $\mathrm{fac}-\mathrm{Tc}(\mathrm{CO})_{3}$ " unit it seems to be easier to get to the meridional coordination geometry of three molecules of CO. In 1977 Mazzi and coworkers described a route to mer$\mathrm{TcCl}(\mathrm{CO})_{3}\left[\mathrm{P}\left(\mathrm{C}_{6} \mathrm{H}_{5}\right)_{3}\right]_{2}$ using the Tc(IV)-educt $\mathrm{TcCl}_{4}\left(\mathrm{P}\left(\mathrm{C}_{6} \mathrm{H}_{5}\right)_{3}\right)_{2}$ under one atmosphere of $\mathrm{CO}$ [28]. The choice of an educt with an odd number of electrons seemed not very convenient since reduction goes with two electron steps thus ending either with $\mathrm{Tc}(0)$ or $\mathrm{Tc}(\mathrm{II})$. We therefore chose well known $\left[\mathrm{TcOCl}_{4}\right]^{-}$ as our educt. In an easy synthesis the very useful mer- $\mathrm{TcCl}(\mathrm{CO})_{3}\left[\mathrm{P}\left(\mathrm{C}_{6} \mathrm{H}_{5}\right)_{3}\right]_{2} 16$ could be prepared in quantitative yield (Figure 10) [29].

It is important that the first reduction step is done with an oxophilic species such as $\mathrm{P}\left(\mathrm{C}_{6} \mathrm{H}_{5}\right)_{3}$. In a one pot synthesis starting with $\mathrm{TBA}\left[\mathrm{TcO}_{4}\right]$ and a two layer system the same compound was found. Trop [30] described in 1979 the synthesis of the compound 17 which obviously could be an intermediate in our pro- 


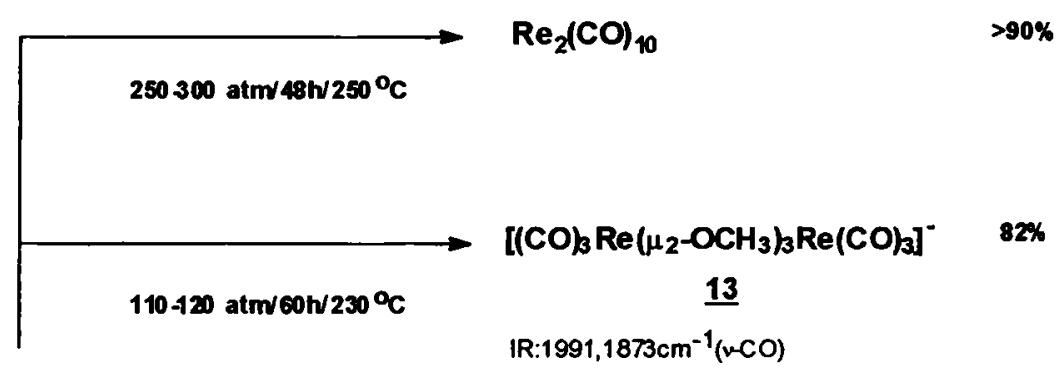

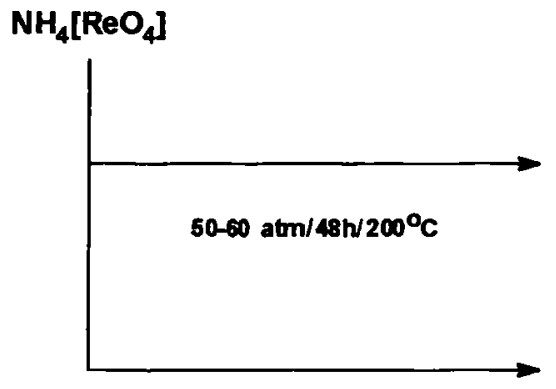

$20-30 \mathrm{~atm} / 48 \mathrm{~h} / 200^{\circ} \mathrm{C}$

\section{$\left[\operatorname{Re}_{3}(\mathrm{CO})_{3}\left(\mu_{2}-\mathrm{OCH}_{3}\right)_{3}\left(\mu_{3}-\mathrm{OCH}_{3}\right)\right]$ \\ 14}

IR:1991,1878, 1867 $\mathrm{cm}^{-1}($ rCO)

$\left[\operatorname{Re}_{4}(\mathrm{CO})_{12}\left(\mu_{3}-\mathrm{OCH}_{3}\right)_{3}\left(\mu_{3}-\mathrm{O}\right)\right]^{-}$

$\underline{15}$

IR:2023,1896 $\mathrm{cm}^{-1}(\mathrm{vCO})$

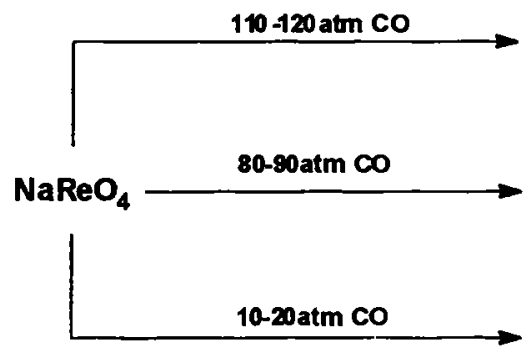

$\operatorname{Re}_{2}\left(\mathrm{CO}_{10}\right.$

$\left[\left(\mathrm{CO}_{3} \operatorname{Re}\left(\mu_{2}-\mathrm{OCH}_{3}\right)_{3} \operatorname{Re}(\mathrm{CO})_{3}\right] \mathrm{Na}^{+}\right.$

tri- and tetranuclear clusters

with $\operatorname{Re}(\mathrm{CO})_{3}\left(\mu_{n}-\mathrm{OCH}_{3}\right)$ units

Fig. 9. Carbonylation of $\mathrm{NH}_{4}\left[\mathrm{ReO}_{4}\right]$ : product distribution under different conditions.

tocol. 17 is orange and insoluble in toluene. Pearlstein et al. found in 1989 [31] that the acetonitrile ligand is substituted by small $\pi$-accepting molecules such as $\mathrm{CO}$ to form deep red complex 18 which also could be expected to be an intermediate in our synthesis. Neither one of these species was observed and if ever they are only present in very low steady state concentrations. The X-ray structure of compound 16 was resolved. The two phosphines are trans to each other and the three carbonyls are in a meridional coordination geometry.

\section{Substitution reactions on mer- $\mathrm{TcCl}(\mathrm{CO})_{3}\left[\left.\mathbf{P}\left(\mathrm{C}_{6} \mathrm{H}_{5}\right)_{3}\right|_{2}\right.$}

We focused special interest again on facial coordinating tridentate amines and $\left[\mathrm{C}_{5} \mathrm{Me}_{5}\right]^{-}$. As shown in Figure 11 substitution occured easily and in good yield. The main products were compounds of the general formula $\left[\mathrm{LTc}(\mathrm{CO})_{2} \mathrm{P}\left(\mathrm{C}_{6} \mathrm{H}_{5}\right)_{3}\right]$. IR-spectroscopy of the raw product let us assume that also some small amounts of $\left[\mathrm{LTc}(\mathrm{CO})_{3}\right]$ had been formed. By consideration of the possible transition states dur- ing the substitution reaction, it is possible that the compound of the form $\left[\mathrm{LTc}(\mathrm{CO})_{3}\right]$ may be the kinetic product. Due to the higher stability of a coordinated phosphine subsequent substitution of a $\mathrm{CO}$ is possible and the yielded products $19-21$ are finally the thermodynamic ones. Trans influence phenomena has also to be considered when discussing substitution mechanism.

Substitution of mer- TcCl$(\mathrm{CO})_{3}\left[\mathrm{P}\left(\mathrm{C}_{6} \mathrm{H}_{5}\right)_{3}\right]_{2}$ by pseudo-allyl ligands such as triazenido or formamidinato derivatives led to the substitution of one chloride and one $\mathrm{CO}$ if starting with the loss of one phosphine and the chloride is observed if starting with mer$\mathrm{TcCl}(\mathrm{CO})_{2}\left[\mathrm{P}\left(\mathrm{CH}_{3}\right)_{2}\left(\mathrm{C}_{6} \mathrm{H}_{5}\right)\right]_{3}$ [32]. Trans influence is clearly responsible for this behaviour and these experiments are in good agreement with our own observations.

Crystal structures of compound 19 and 20 could be resolved. In both compounds the Tc $-\mathrm{N}$ bond length trans to the Tc-P bond is significantly shorter than the two others. This data again indicates the strong trans influence of $\mathrm{CO}$ ligands and has been observed 


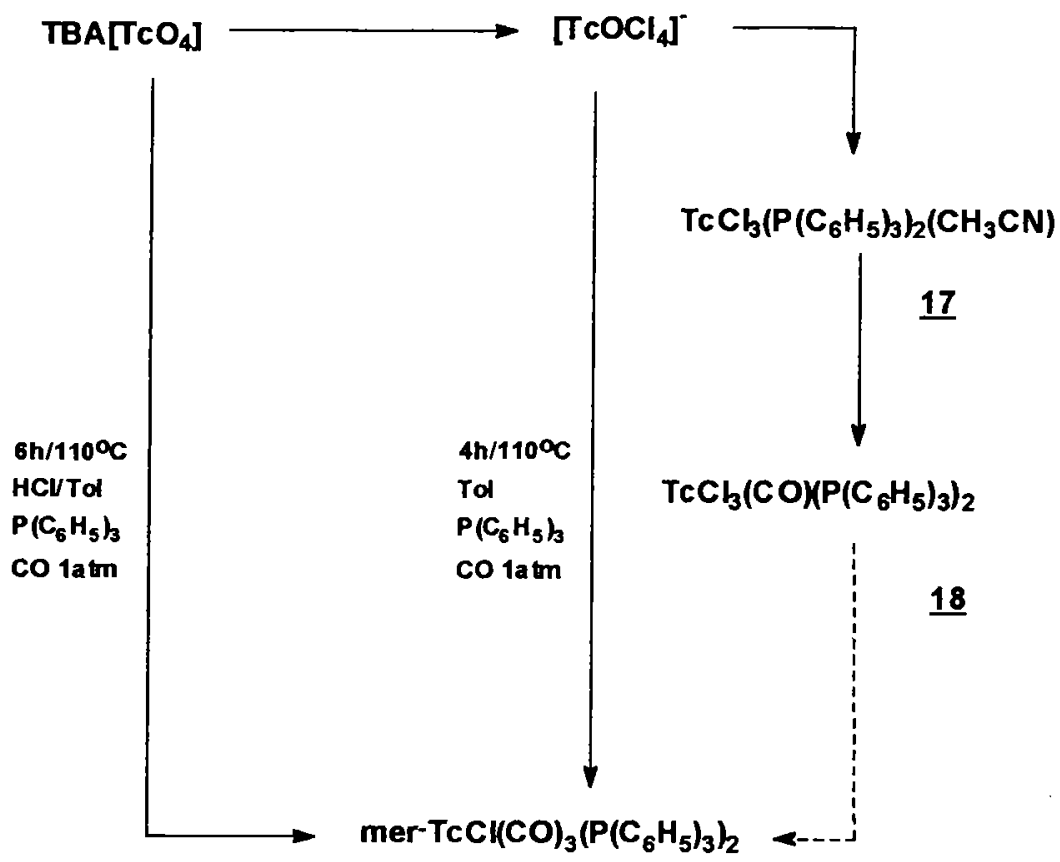

$96 \% \quad 16$

Fig. 10. Synthesis conditions for mer- $\mathrm{TcCl}(\mathrm{CO})_{3}\left[\mathrm{P}\left(\mathrm{C}_{6} \mathrm{H}_{5}\right)_{3}\right]_{2}$ using $\mathrm{TBA}\left[\mathrm{TcO}_{4}\right]$ or $\mathrm{TBA}\left[\mathrm{TcOCl}_{4}\right]$ as an educt.

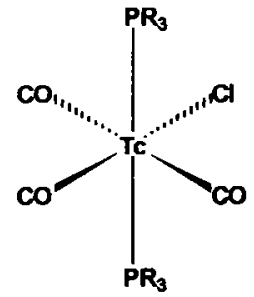

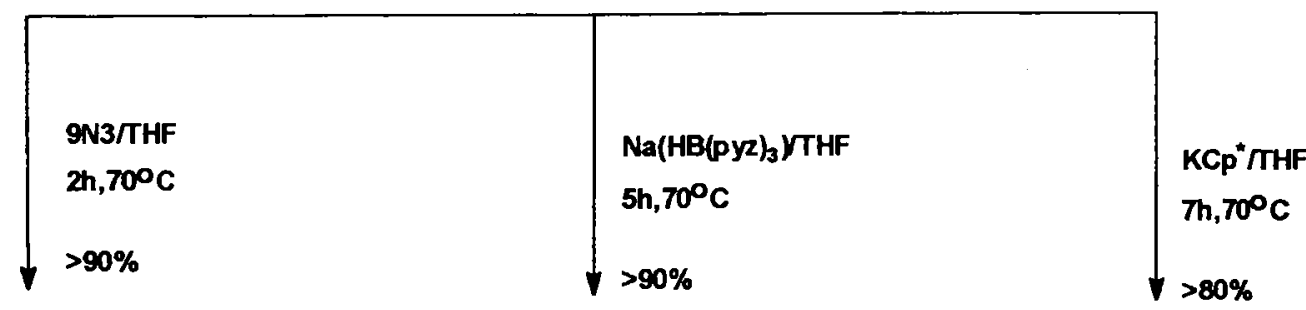

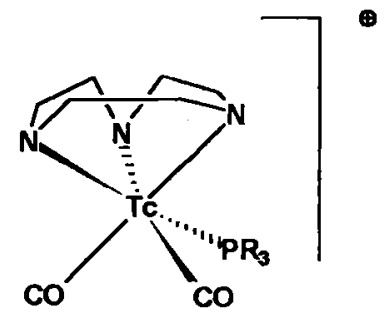

$\underline{19}$

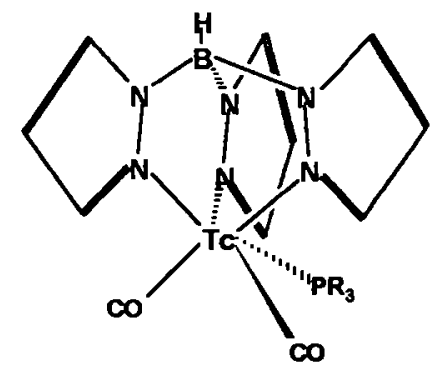

$\underline{20}$

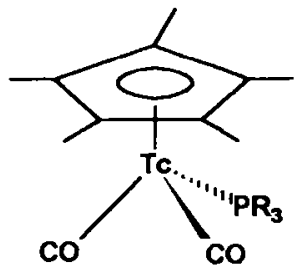

$\underline{21}$

99TCNMR: 934ppm

-1198ppm

$-1782 p p m$

Fig. 11. Substitution reactions on mer- $\mathrm{TcCl}(\mathrm{CO})_{3}\left[\mathrm{P}\left(\mathrm{C}_{6} \mathrm{H}_{5}\right)_{3}\right]_{2}$ using tridentate facial coordinating ligands. 
in other systems as well. The Tc-P bond length in compound $\mathbf{2 0}$ is therefore significantly longer than in 19. Trans influence of coordinated pyrazolyl is consequently stronger than for secondary amines.

\section{Conclusion}

Organometallic chemistry of technetium in high as well as in low oxidation states offers a lot of aspects not known from other elements. The synthesis of $\mathrm{CH}_{3} \mathrm{TcO}_{3}$ as well as substitution reactions are different from its rhenium analog owing to the significantly higher oxidation power of this complex. Its characterization and subsequent appliance to catalytic processes reveals new processes which do not take place for any of the other elements of the seventh triad. $\mathrm{CH}_{3} \mathrm{TcO}_{3}$ oxidizes alkene derivatives stereospecifically to cis 1,2 diols and thus is comparable to osmium but not to rhenium or manganese.

A new carbonylation of $\mathrm{NaTcO}_{4}$ at moderate pressure yields selectively the $\mathrm{Tc}(\mathrm{I})$-cluster 9 which proved to be a useful educt for substitution with facial coordinating tridentate ligands such as $\mathrm{C}_{6} \mathrm{H}_{6}$, $\mathrm{HC}_{5} \mathrm{Me}_{5}$ and ane-9N3. The cluster itself contains an isocarbonyl bonding to the sodium included in the cuban like structure. Similar synthesis with perrhenate yielded the same class of products but, as far as investigated, two and four nuclear species also. Reaction with technetium again takes place very much faster and under more moderate reaction conditions, again a sign that the higher oxidation potential offers a different behaviour also for low oxidation state. We emphasize that the synthesis of the technetium compound induced investigations with rhenium even though usually it is the other way round.

Carbonylation of $\mathrm{TBA}\left[\mathrm{TcO}_{4}\right]$ at one atmosphere $\mathrm{CO}$ pressure finally allowed access to mer$\mathrm{TcCl}(\mathrm{CO})_{3}\left[\mathrm{P}\left(\mathrm{C}_{6} \mathrm{H}_{5}\right)_{3}\right]_{2}$ in quantitative yields. This important starting material can be used for many substitution reactions with tridentate facial coordinating ligands.

\section{References}

1. Herrmann, W. A., Okuda, J.: Angew. Chem. Int. Ed. Engl. 25, 1092 (1986)

2. Herrmann, W. A., Watzlowik, P., Kiprof, P.: Chem. Ber. 124, 1101 (1991).

3. Marz, D. W.: Ph. D. Thesis Technische Universität München 1990.
4. Guest, A., Lock, C. J. L.: Can. J. Chem. 50, 1807 (1972).

5. Thomas, J. A., Davison, A.: Inorg. Chim. Acta 190, 231 (1991).

6. Thomas, J. A., Davison, A.: Inorg. Chem. 31, 1976 (1992).

7. Burrell, A. K., Bryan, J. C.: Organometallics 11, 3501 (1992).

8. Kaden, L., Lorenz, B., Rummel, S., Schmidt, K., Wahren, M.: Inorg. Chim. Acta 142, 1 (1988).

9. Abrams, M. J., Davison, A., Jones, A. G., Costello, C. E.: Inorg. Chem. 22(20), 2798 (1983).

10. Wester, D. W., Coveney, J. R., Nosco, D. L., Robbins, M. S., Dean, R. T.: J. Med. Chem. 34, 3284 (1991).

11. Hileman, J. C., Huggins, D. K., Kaesz, J.: J. Am. Chem. Soc. 83, 2953 (1961).

12. Bailey, M. F., Dahl, L. F.: Inorg. Chem. 4, 1140 (1965).

13. a) Herrmann, W. A., Kuchler, J. G., Felixberger, J. K., Herdtweck, E.: Angew. Chem. Int. Ed. Engl. 29, 394 (1988).

b) Beattie, I. R., Jones, P. J.; Inorg. Chem. 18, 2318 (1979).

c) Mertis, K., Gibson, J. F., Wilkinson, G.: J. Chem. Soc. Chem. Commun. 93 (1974).

14. Herrmann, W. A., Alberto, R., Kiprof, P., Baumgärtner, F.: Angew. Chem. 102, 208 (1990).

15. Herrmann, W. A., Weichselbaumer, G., Herdtweck, E.: J. Organomet. Chem. 372, 371 (1989).

16. Sharpless, K. B., Teranishi, A. Y., Baeckvall, J. E.: J. Am. Chem. Soc. 99, 3120 (1977)

17. Pearlstein, R. M., Davison, A.: Polyhedron 7(19), 1981 (1988).

18. Hileman, J. C., Huggins, D. K., Kaesz, J.: J. Am. Chem. Soc. 83, 2953 (1961).

19. Hieber, W., Herget, C.: Angew. Chem. 73, 579 (1961).

20. Heinekey, D. M., Crocker, L. S., Gould, G. L.: J. Organomet. Chem. 342, 243 (1988).

21. Herrmann, W. A., Alberto, R., Bryan, J. C., Baumgärtner, F., Sattelberger, A.: Chem. Ber. 124, 1107 (1991).

22. Darensbourg, M.: Progr. Inorg. Chem. 33, 221 (1985).

23. O'Connell, L. A., Pearlstein, R. M., Davison, A., Thornback, J. R., Kronauge, J. F., Jones, A. G.: Inorg. Chim. Acta 161, 39 (1989).

24. Mihalios, D.: Ph. D. Thesis Technische Universität München 1992.

25. Herrmann, W. A., Kiprof, P., Rypdal, K., Tremmel, J., Blom, R., Alberto, R., Behm, J., Albach, R. W., Bock, H., Solouki, B., Mink, J., Lichtenberger, D., Gruhn, N. E.: J. Am. Chem. Soc. 113, 3450 (1991).

26. Kanellakopulos, B., Nuber, B., Raptis, K., Ziegler, M. L.: Angew. Chem. Int. Ed. Engl. 28, 1055 (1989).

27. Wolowiec, S., Kochi, J. K.: Inorg. Chem. 30, 1215 (1991).

28. Mazzi, U., Bismondo, A., Kotsev, N., Clemente, D. A.: J. Organomet. Chem. 135, 177 (1977).

29. Alberto, R., Herrmann, W. A., Kiprof, P., Baumgärtner, F.: Inorg. Chem. 31, 895 (1992).

30. Trop, H. S.: Ph. D. Thesis Massacchusetts Institute of Technology 1979.

31. Pearlstein, R. M., Davis, W. M., Jones, A. G., Davison, A.: Inorg. Chem. 28, 3332 (1989).

32. Marchi, A., Rossi, R., Duatti, A., Magon, L., Bertolasi, V., Ferretti, V., Gilli, G.: Inorg. Chem. 24, 4744 (1985). 
